\title{
Hydration Kinetics and Fire Resistance of Recycled Low Grade Alumino-silicate Refractory Bricks Waste-metakaolin Composite Cement Pastes
}

\author{
Ahmed A. Amer* and Samir El-Hoseny A \\ Chemistry Department., Faculty of Science, Zagazig University, Egypt.
}

\begin{abstract}
THE AIM of the present work is to study the effect of low grade aluminosilicate refractory bricks (ASRBs) with metakaolin (MK) on the hydration properties and the fire resistance of composite cement pastes at elevated temperature up to $800{ }^{\circ} \mathrm{C}$. The composite cement are composed of constant proportion of ordinary Portland cement (OPC) $(80 \mathrm{wt} \%)$ with variable amounts of ASRBs and MK. The substitution of $20 \%$ ASRBs with MK increases the water of consistency and retarded the initial as well as the final setting times, whereas the free lime contents and the bulk density decreases with MK. The compressive strength increases with MK content which enhanced the early and long term strength. It acts also as micro-filler that accelerates initial cement hydration. The fire resistance of composite cement pastes was evaluated up to $800{ }^{\circ} \mathrm{C}$ with rate of firing $5{ }^{\circ} \mathrm{C} / \mathrm{min}$. and soaking time for $2 \mathrm{~h}$. The physico-mechanical properties such as weight loss, bulk density and compressive strength were determined at each firing temperature. Moreover, some selected samples were investigated by using XRD, DTA/TG and SEM techniques analyses. Cement pastes containing $20 \mathrm{wt} \% \mathrm{ASRBs}(\mathrm{PC}-\mathrm{A})$ is the optimum composite cement paste which gives high bulk density and compressive strength. It can be concluded the cement paste PC-A has a good fire resistance paste.
\end{abstract}

Keywords: MK, ASRBs, DTA/TG, XRD, Hydration, Fire resistance cement.

\section{Introduction}

Pozzolanas are naturally or artificial silicieous and aluminous materials, which possesses little or non-cementitious properties. But, in a finally divided form in the presence of water, they react with lime $(\mathrm{CH})$ at room temperature to form calcium silicate and calcium aluminosilicate hydrates (C-S-H and C-A-S-H, respectively) $[1,2]$. Presently, the use of pozzolan incorporated in mortar and concrete has become much common throughout the world. The application of such material is increasing due to their superior structural performance, environmental friendliness and energy conservation implications [3]. Pozzolanas such as Fly ash, silica fume, Rice husk ash, ground granulated blast furnace slag and Metakaolin are commonly used for partial replacement of cement. Each of the pozzolanic materials induces various characteristics which have been explored by the researchers throughout the world [4].

Metakaolin, (MK) $\mathrm{Al}_{2} \mathrm{Si}_{2} \mathrm{O}_{7}$, is a largely amorphous product of kaolinite $\mathrm{Al}_{2}(\mathrm{OH})_{4} \mathrm{Si}_{2} \mathrm{O}_{5}$, after calcination at a temperatures between 500 and $850^{\circ} \mathrm{C}$. It contains silica and alumina in an active form which will react with $\mathrm{CH}$, in the presence of water, forming cementitious C-S-H gel, together with crystalline products, which include calcium aluminate and aluminosilicate hydrate $\left(\mathrm{C}_{3} \mathrm{AH}_{6}, \mathrm{C}_{4} \mathrm{AH}_{13}\right.$ and $\left.\mathrm{C}_{2} \mathrm{ASH}_{8}\right) \quad[5,6]$. Many researchers have a lot of interest in $\mathrm{MK}$ as it has been found to possess both pozzolanic and microfiller characteristics [7-10].

Fired low grad aluminosilicate refractory bricks (ASRBs) are commonly found in furnace as well as fire places. ASRBs are usually composed

\footnotetext{
* Corresponding author e-mail:drahmed.amer@zu.edu.eg +0201149970663

DOI : 10.21608/EJCHEM.2017.3479

C2017 National Information and Documentaion Center (NIDOC)
} 
of a combination of clay minerals with silica, alumina or kaolin. There are few tries recorded for use aluminosilicate refractory bricks fired at temperature above $1500{ }^{\circ} \mathrm{C}$ as supplementary cementitious materials (SCM's). In a previous work [11], the pozzolanic activity of ASRBs with $\mathrm{CH}$ up to $30 \mathrm{wt} \%$ has somewhat potential to be used as a pozzolanic and filling material in cement based system. The substitution of 5-10 wt $\%$ of OPC by ASRBs gives higher compressive strength than that of OPC up to 90 days.

Concrete generally provides adequate fire resistance for most applications. It is well known for its capacity to endure high temperatures and fires owing to its low thermal conductivity and high specific heat [12]. However, it does not mean that fire, or high temperatures do not affect concrete at all. The durability properties of concrete are significantly affected at elevated temperatures [13-19]. At temperatures above $300{ }^{\circ} \mathrm{C}$, evaporation of the bound water increases the deterioration of concrete and thereby the compressive strength decreases [20]. When temperature exceeds $400{ }^{\circ} \mathrm{C}, \mathrm{C}-\mathrm{S}-\mathrm{H}$ disintegrates [13]. Thus, the critical exposure temperature range is $400-800{ }^{\circ} \mathrm{C}$ in terms of compressive strength loss. The effect of elevated temperatures on the mechanical durability properties of concrete has been investigated in order to produce fire resistant materials [21-23]. The aim of the present work is to study the effect of substitution of ASRBs with MK on the hydration properties and the fire resistance of composite cement pastes at temperature up to $800{ }^{\circ} \mathrm{C}$. Moreover, some selected pastes were investigated by using XRD, DTA/TG and SEM technique analyses.

\section{Materials and Methods}

The materials used in this work were ordinary Portland cement (OPC) and fired clay refractory bricks (ASRBs) as waste product supplied from Suez Cement Company, Suez. Kaolinite clay was supplied from Abu Zneima zone, South of Sinai, Egypt. The physico-chemical analysis of starting materials is shown in Table 1.

The surface area was made using Blain apparatus according to ASTM [24]. The mineralogical composition of ASRBs and MK were determined from XRD patterns in Fig. 1a $\&$ b. XRD pattern of ASRBs shows the presence of quartz as the main mineral and cristobalite as well as mullite in addition to amorphous phase. XRD pattern of MK illustrates the presence of Egypt.J.Chem. 60 , No.3 (2017) quartz as the main mineral and an amorphous phase (aluminosilicate), which is formed as a result of reaction between active $\mathrm{SiO}_{2}$ and $\mathrm{Al}_{2} \mathrm{O}_{3}$ as well as fluxing oxides as impurities at high temperature. The mix composition of the composite cements is seen in Table 2. The ASRBs-MK composite cement is prepared by the substitution of $20 \mathrm{wt} \%$ ASRBs with MK. The dry constituents were mixed in a porcelain ball mill with four balls for 1 hour to attain complete homogeneity and then kept in airtight containers. The water of standard consistency, the initial and final setting times were determined according to ASTM using Vicat apparatus [25]. The mixing of cements was carried out with the required water of standard consistency and cured at $100 \%$ relative humidity at $23 \pm 2{ }^{\circ} \mathrm{C}$ for 24 hours as described in a previous work [2], then demoulded, cured under tap water up to 90 days. The hydration of the pastes was stopped using an acetone-methanol mixture [26], then dried at $70{ }^{\circ} \mathrm{C}$ for 2 hours and kept in airtight containers. The combined water,

TABLE 1. Physico-chemical analysis of OPC, ASRBs and MK.

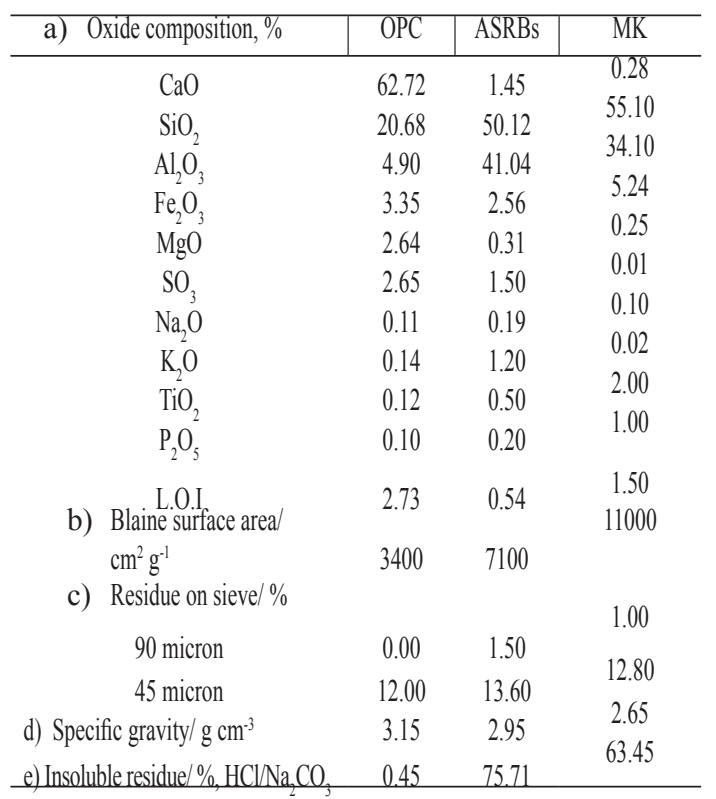

TABLE 2. The mix composition of the investigated mixes, $\%$.

\begin{tabular}{cccc}
\hline Mix. No. & OPC & ASRBs & MK \\
\hline OPC & 100 & 00 & 00 \\
PC-A & 80 & 20 & 00 \\
PC-AM & 80 & 10 & 10 \\
PC-M & 80 & 00 & 20 \\
\hline
\end{tabular}




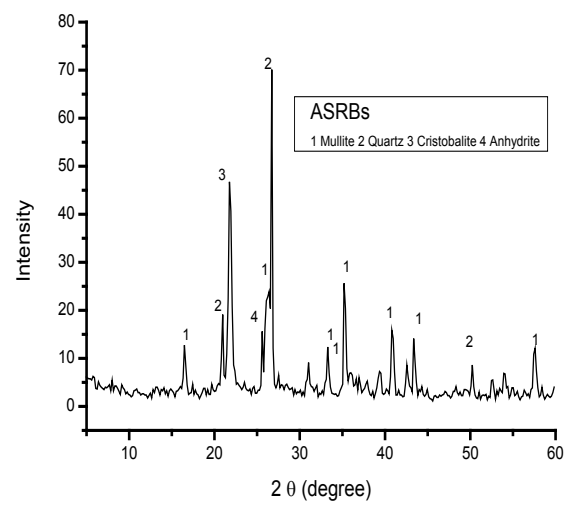

Fig.1a. XRD pattern of ASRBs [11].

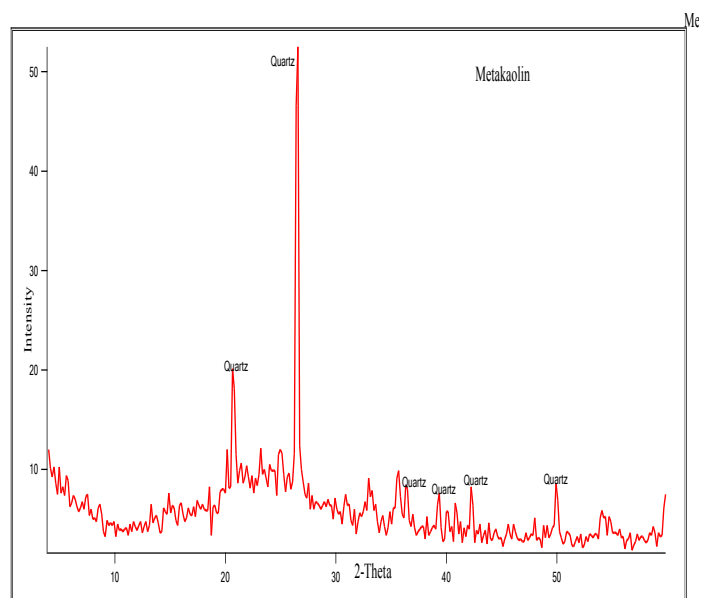

Fig. 1b . XRD pattern of MK [10].

free lime contents [27], as well as insoluble residue contents, bulk density and compressive strength [28] of composite cement pastes were determined. Some selected hydrated pastes were investigated using XRD, DTA/TG and SEM techniques. Thermally heated pastes were prepared using the standard water of consistency. The samples were demoulded after $24 \mathrm{~h}$, cured for 28 days under tap water, dried for $24 \mathrm{~h}$ at $105{ }^{\circ} \mathrm{C}$, then subjected to thermal treatment for $2 \mathrm{~h}$ at $250,450,600$ and $800{ }^{\circ} \mathrm{C}$ with $5{ }^{\circ} \mathrm{C} / \mathrm{min}$ rate of heating, then cooled to room temperature in the furnace. Bulk density and compressive strength of treated cement pastes were determined after immersing the pastes overnight under kerosene [2]

The XRD technique was carried out using BRUXER, Axs D8 ADVANCE A8 and GERMANY Diffractometer as described in a previous work [10]. The differential thermal analyzer of the type Simultaneous TGA/DSC MODEL SDTQ600 (USA) was also used. A sample of $50-\mathrm{mg}(-53 \mathrm{um})$ was used at $20^{\circ} \mathrm{C} / \mathrm{min}$ heating rate. The interpretation of the thermal charts was based on the data given by Plummer \& Mackenzie [29]. The microstructure of the heat treated samples was studied by using SEM of freshly fractured specimens, coated with a 300-400 A layer of gold, using JEOL apparatus with high resolution SEM [30].

\section{$\underline{\text { Results and Discussion }}$}

Hydration kinetics of recycled aluminosilicate refractory bricks-metakaolin composite cement pastes

Water of consistency and setting time

The water of consistency, initial and final setting times of the composite cement pastes are represented in Fig. 2. Mix PC-A (20 wt., $\%$ ASRBs) filled cement paste gives the lower water of consistency in comparison with OPC as well as other composite cement pastes. This is due to that ASRBs has some crystalline phases such as quartz, cristobalite and mullite which have low pozzolanic activity substitution of $20 \mathrm{wt} \%$ ASRBs with MK

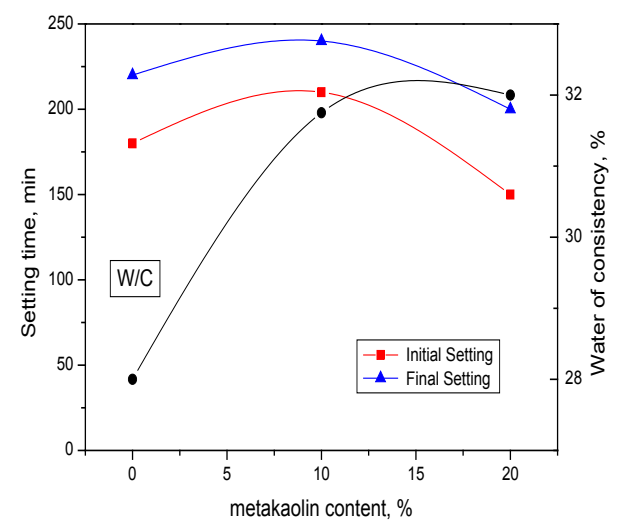

Fig. 2. Water of consistency, initial and final setting time of composite cement paste of ASRBs and MK.

increases the water of consistency due to the high reactivity of MK which has high specific surface area $\left(11,000 \mathrm{~cm}^{2} / \mathrm{g}\right)$ resulting high water adsorption/absorption as well as the presence of the amorphous structure in MK [31]. It is clear that substitution of more than 10 wt $\%$ of ASRBs with MK somewhat retards the initial and final setting times. This is due to the pozzolanic activity of MK and ASRBs as 
well as the increase of water/cement $(\mathrm{w} / \mathrm{c})$ ratio which favors the formation of ettringite [32]. As ASRBs content decreases up to complete substitution the initial and final setting times are accelerated due to the high pozzolanic activity of MK [33].

\section{Combined water content}

The combined water contents of composite cement pastes are represented up to 90 days in Fig. 3. The combined water content increases gradually with curing time for all cement pastes due to the progress of hydration. It is clear that the combined water increases with MK content which is attributed to increase the amount of water of consistency as well as its high specific area $\left(11000 \mathrm{~cm}^{2} / \mathrm{g}\right)$ and amorphous material. Mix PC-

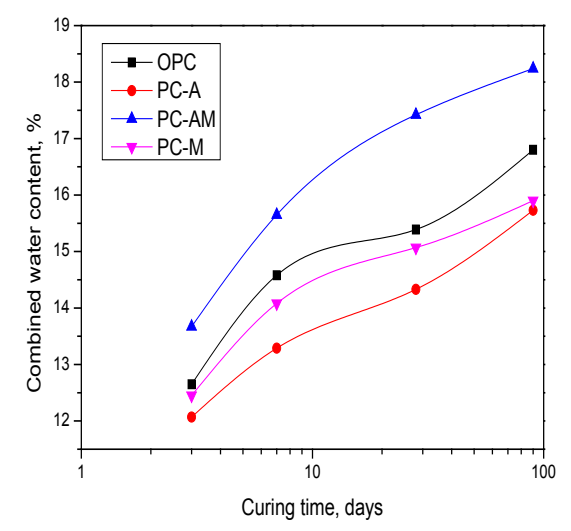

Fig. 3. Chemically combined water of hydrated OPC and composite cement pastes up to 90 days.

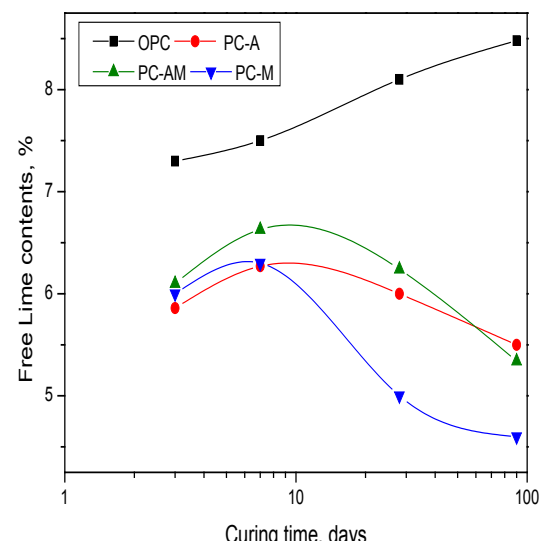

Fig. 4. Free lime contents of hydrated OPC as well as composite cement pastes up to 90 days
AM gives higher combined water than all cement pastes. This is mainly due to the presence of two Pozzolanic materials which act as nucleating agent [33], that increases the rate of hydration of OPC and Pozzolanic reaction between ASRBs and MK with liberated lime to form more hydration products.

Free lime contents

The free lime contents of OPC as well as composite cement pastes are plotted up to 90 days in Fig. 4. The free lime content of the OPC paste increases up to 90 days; due to the continuous hydration of the $\mathrm{C}_{3} \mathrm{~S}$ and $\mathrm{B}_{-} \mathrm{C}_{2} \mathrm{~S}$, liberating free lime $(\mathrm{CH})$. The free lime contents of all composite cement pastes increase with curing time up to 7 days, then decrease up to 90 days. This is due to the liberation of free lime during hydration of Portland cement pastes exceeds

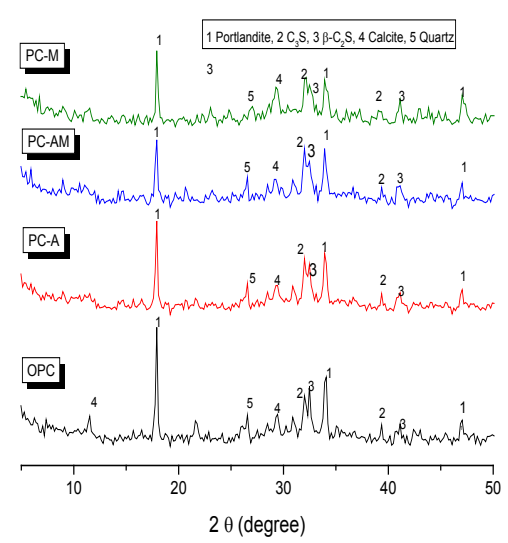

Fig. 5. XRD patterns of hydrated OPC and composite cement pastes cured up to 28 days.

the rate of consumption by pozzolanic reaction of ASEBs as well as MK. On the other hand, the substitution of ASRBs with 20 wt., \% MK decreases the free lime up to 90 days due to the higher pozzolanic activity of MK than ASRBs to react with liberated lime.

XRD Analysis

Figure 5 illustrates the XRD patterns of hydrated cement pastes cured up to 28 days. The figure shows the presence of portlandite in all cement pastes but decreases with the substitution of ASRBs with MK. Mix PC-M cement paste shows the lower $\mathrm{CH}$ than the other composite mixes (PC$\mathrm{A}$ and $\mathrm{PC}-\mathrm{AM}$ ), and lastly OPC. The anhydrous phases of $B-C_{2} S$ and $B-C_{2} S$ are still present. The quartz peaks are also still present in PC-M cement pastes due to its unhydraulic properties. On the

Egypt.J.Chem. 60 , No.3 (2017) 
other hand, the $\mathrm{CaCO}_{3}$ peaks decrease with $\mathrm{MK}$ content due to the effect of $\mathrm{CO}_{2}$ in the presence of $\mathrm{H}_{2} \mathrm{O}$ to form $\mathrm{Ca}\left(\mathrm{HCO}_{3}\right)_{2}$. The OPC paste gives the higher rate of carbonation due to its higher content of $\mathrm{Ca}(\mathrm{OH})_{2}$. ASRBs have somewhat pozzolanic activity and filler effects [11]. The C-S-H gel is overlapped with $\mathrm{CaCO}_{3}$ peak.

\section{Thermal Analysis}

Figure 6 illustrates the DTA/TG thermograms of the hydrated mix PC-A pastes cured at 3 and 90 days. The DTA curves show the occurrence of four endothermic peaks. The first endothermic peak located below $100^{\circ} \mathrm{C}$ is due to the re-

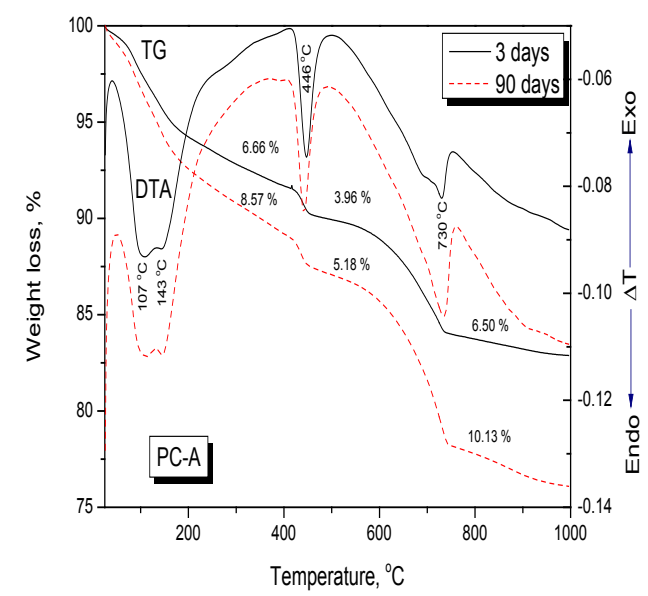

Fig. 6. DTA/TG curves of hydrated mix PC-A cured at 3 and 90 days

moval of free water and the decomposition of the amorphous part of C-S-H. The second endotherm 130-160 ${ }^{\circ} \mathrm{C}$ represents the decomposition of small amount of crystalline part of C-S-H, C-A-H, C-A$\mathrm{S}-\mathrm{H}$ as well as $\mathrm{C}_{2} \mathrm{ASH}_{8}[2,34]$, with a mass loss of 6.66 and $8.57 \%$ for 3 and 90 days, respectively. The endothermic peak located at about $160{ }^{\circ} \mathrm{C}$ increases with curing time due to the formation of excessive amounts of C-A-H and C-A-S-H as well as C-S-H. The third endotherm in range 410$490{ }^{\circ} \mathrm{C}$ is due to the dehydroxylation of $\mathrm{CH}[35$, 36], with a mass loss of 3.96 and $5.18 \%$ for 3 and 90 days, respectively. These values indicate that the ASRBs have little pozzolanic activity with $\mathrm{CH}$. The fourth endotherm with the range 685$760{ }^{\circ} \mathrm{C}$ due to the decomposition of amorphous and crystalline $\mathrm{CaCO}_{3}[35,37]$, with a mass loss of 6.50 and $10.13 \%$ for 3 and 90 days, respectively. These phases are formed as a result of the pozzolanic activity of ASRBs with $\mathrm{CH}$ [11]. The main features of the curves are characterized by the relative increase of C-S-H, C-A-H and C-A-S$\mathrm{H}$ peaks with ASRBs. The $\mathrm{CaCO} 3$ is still present, due to the carbonation of $\mathrm{CH}$ which has a highly amorphous character, and readily attacked by the atmospheric $\mathrm{CO} 2$. This is in an agreement with that of DTA.

Figure 7 shows the DTA/TG curves of PCAM hydrated cement pastes cured at 3 and 90 days. The first two endothermic peaks within temperature range of 90-220 oC are mainly due to the dehydration of interlayer water of $\mathrm{C}-\mathrm{S}-\mathrm{H}$

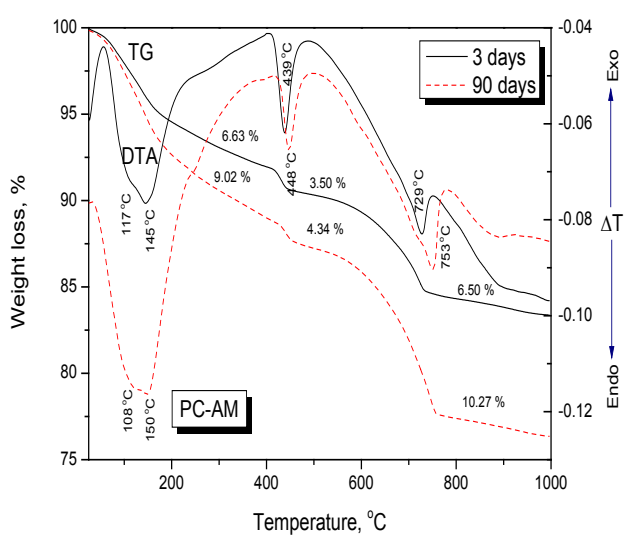

Fig. 7. DTA/TG curves of hydrated mix PC-AM cured at 3 and 90 days.

and $\mathrm{C}-\mathrm{A}-\mathrm{H}$ or $\mathrm{C}-\mathrm{A}-\mathrm{S}-\mathrm{H}$ as well as the presence of carboaluminate [36], with a mass loss of 6.63 and $9.02 \%$ for 3 and 90 days, respectively. The third endothermic peak located at range $410-475{ }^{\circ} \mathrm{C}$ is due to the decomposition of $\mathrm{CH}$ [35], with a mass loss of 3.50 and $4.34 \%$ for 3 and 90 days, respectively. The last endothermic peak located with temperature range 700 $780{ }^{\circ} \mathrm{C}$ is due to the decomposition of $\mathrm{CaCO}_{3}$ $[35,37]$, with mass loss of 6.50 and $10.27 \%$ for 3 and 90 days, respectively. It is clear that the second endothermic peak located at about 150 ${ }^{\circ} \mathrm{C}$ increases with curing time due to the formation of excessive amounts of C-A-H and C-A$\mathrm{S}-\mathrm{H}$ as well as C-S-H. These phases are formed as a result of the pozzolanic reaction of both ASRBs and MK with $\mathrm{CH}$. The main features of the curves are characterized by the relative decrease of the peak area of $\mathrm{CH}$ and increase 


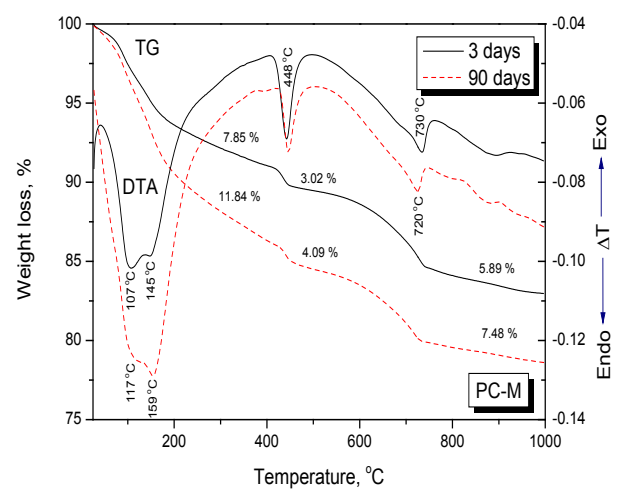

Fig. 8. DTA/TG curves of hydrated mix PC-M cured at 3 and 90 days.

of C-S-H, C-A-H and C-A-S-H peaks with both ASRBs and MK. The decrease of the $\mathrm{CH}$ endothermic peak is due to the consumption of the residual lime by pozzolanic reaction with active silica and alumina containing ASRBs as well as MK. Also, the $\mathrm{CaCO}_{3}$ is still present, due to the carbonation of $\mathrm{CH}$ by atmospheric $\mathrm{CO}_{2}$. This is in an agreement with the results of DTA.

Figure 8 illustrates the DTA/TG thermograms of hydrated cement pastes PC-M cured at 3 and 90 days. There are four endothermic peaks located within temperature range $25-1000{ }^{\circ} \mathrm{C}$. The first two endothermic peaks at range $85-160$ oC are mainly due to the dehydration of interlayer water of C-S-H and C-A-H or CA-S-H as well as carboaluminate [36], with a mass loss of 7.85 and $11.84 \%$ for 3 and 90 days, respectively. This means that MK acts as micro-filler and nucleating agent which accelerates the rate of hydration and then the combined water increases. This is in an agreement with the results of DTA. The third endotherm at 448-443 ${ }^{\circ} \mathrm{C}$ is due to the dehydroxylation of $\mathrm{CH}$ [35], with a mass loss of 3.02 and $4.09 \%$ for 3 and 90 days, respectively. The last endothermic peak located at $730-738^{\circ} \mathrm{C}$ is due to the decomposition of $\mathrm{CaCO}_{3}[35,37]$, with mass loss of 5.89 and $7.48 \%$ for 3 and 90 days, respectively. Also, the $\mathrm{CaCO}_{3}$ is still present, due to the carbonation of $\mathrm{CH}$ by atmospheric $\mathrm{CO}_{2}$.

Figure 9 represents the DTA/TG thermograms of the hydrated OPC and composite cement pastes at 90 days. The first thermal degradation stage in the temperature range $77-192{ }^{\circ} \mathrm{C}$ with the maximum decomposition peak DTGmax at 98, 150, 150 and $156^{\circ} \mathrm{C}$ corresponding to the dehydration of C-S-H, C-A-H and C-A-S-H with a weight loss of $9.67,8.57,9.02$ and $11.84 \%$ for OPC, PC-A, PC-Am and PC-M, respectively. The third thermal stage in the temperature range $409-483{ }^{\circ} \mathrm{C}$

Egypt.J.Chem. 60 , No.3 (2017) with the maximum decomposition peak DTGmax at $\approx 441{ }^{\circ} \mathrm{C}$ corresponding to the dehydroxylation of $\mathrm{Ca}(\mathrm{OH})_{2}$ with a weight loss of $6.804,5.18,4.34$ and $4.09 \%$ for OPC, PC-A, PC-Am and PC-M, respectively. The fourth thermal decomposition step proceeds at $695-790{ }^{\circ} \mathrm{C}$ with the maximum decomposition peak DTGmax at 714, 728, 748 and $728{ }^{\circ} \mathrm{C}$ corresponding to the decomposition of $\mathrm{CaCO}_{3}$ with a weight loss of $5.68,10.13,10.27$ and $7.48 \%$ for OPC, PC-A, PC-Am and PC-M, respectively. It is clear that intensities of the endothermic peaks characteristic for hydrated products is large with PC-M due to the pozzolanic activity of MK.

\section{Insoluble residue}

The insoluble residue (unreacted part) contents of hydrated OPC and composite cement pastes are graphically represented up to 90 days in Fig. 10. It is clear that the insoluble residue content decreases with curing time as well as MK content, due to the decrease of ASRBs content and the high reactivity of MK with glassy phase which reacts with $\mathrm{CH}$. Mix PC-M poz-

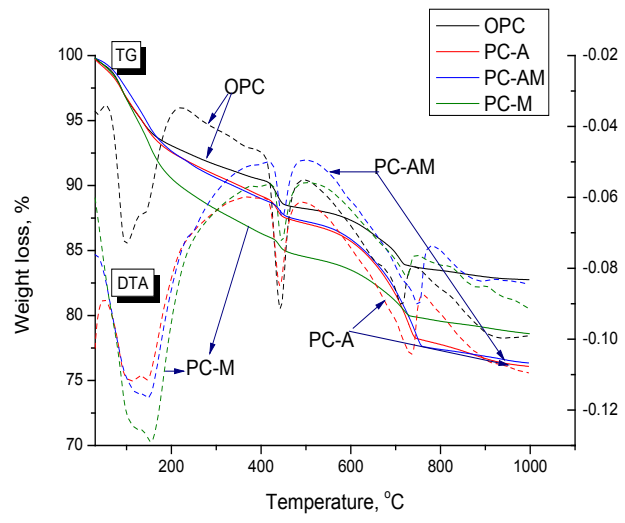

Fig. 9. DTA/TG thermograms of the hydrated OPC and cement pastes at 90 days.

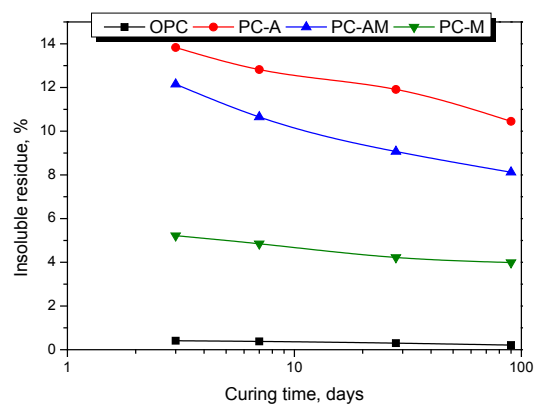

Fig. 10. Insoluble residue contents of hydrated OPC and composite cement pastes up to 90 days. 


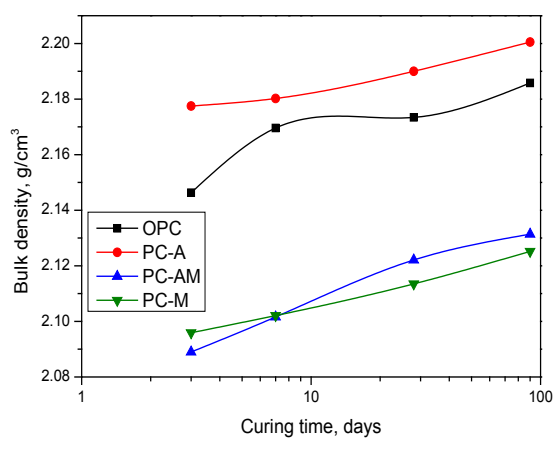

Fig. 11. The bulk density of OPC as well as composite cement pastes cured up to 90 days

zolanic cement paste shows the lower insoluble residue contents than other composite cement pastes. The increase of insoluble residue of composite cement PC-A is mainly due to the high amount of crystalline phases in ASRBs such as quartz, cristobalite and mullite which are unhydraulic in comparison to MK. OPC pastes show very small amount of insoluble residue due to the absence of ASRBs and MK.

\section{Bulk density}

The bulk density of hydrated OPC and composite (ASRBs - MK) cement pastes are represented up to 90 days in Fig. 11. The bulk density increases with curing time for all cement pastes due to the progress of hydration giving more hydration products that fill some of pores of cement pastes which increase the bulk density of cement paste. The bulk density decreases with MK content due to its lower specific gravity $\left(2.65 \mathrm{~g} / \mathrm{cm}^{3}\right)$

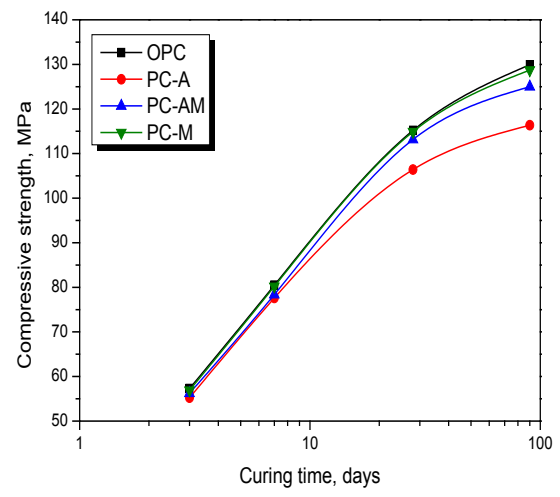

Fig. 12. Compressive strength of hydrated OPC and composite cement pastes up to 90 days. in comparison with ASRBs $\left(2.95 \mathrm{~g} / \mathrm{cm}^{3}\right)$ and the increase of the water of consistency with MK content. So, PC-A paste shows the higher bulk density than OPC as well as other composite cement pastes. The higher bulk density of PC-M than $\mathrm{PC}-\mathrm{AM}$ at $3-7$ days is mainly due to the more hydraulic property of MK than ASRBs.

\section{Compressive strength}

The compressive strength of OPC and composite cement pastes is plotted in Fig. 12. The compressive strength increases with curing time for all cement pastes up to 90 days. This is mainly due to the increase of the hydration products, especially C-S-H which accumulates within the available pores giving high strength [38]. The $\mathrm{C}-\mathrm{S}-\mathrm{H}$ phase is the most cementitious or binding phase and hence contributes to the strength of cement paste. The compressive strength increases with MK content due to its pozzolanic activity which is higher than ASRBs as well as MK gives enhanced early and long term strength [6]. It acts also as micro-filler that accelerates initial cement hydration and rapidly consumes the portlandite liberated from OPC to give additional hydration products [39]. Mix PC-M cement paste gives compressive strength nearly equal to the neat cement paste.

Effect of fire on the physico-mechanical properties of cement pastes

When hardened Portland cement paste is exposed to high temperatures, complex physicochemical transformation takes place. The main components of cement paste, $\mathrm{C}-\mathrm{S}-\mathrm{H}$ and $\mathrm{CH}$, dehydrated at high temperature $\left(>105^{\circ} \mathrm{C}\right)$. This leads to irreversible changes of the structure of cement paste [40] and the structure of cement paste undergoes substantial changes. The phases present in cement paste exhibit different heat-induced defor-

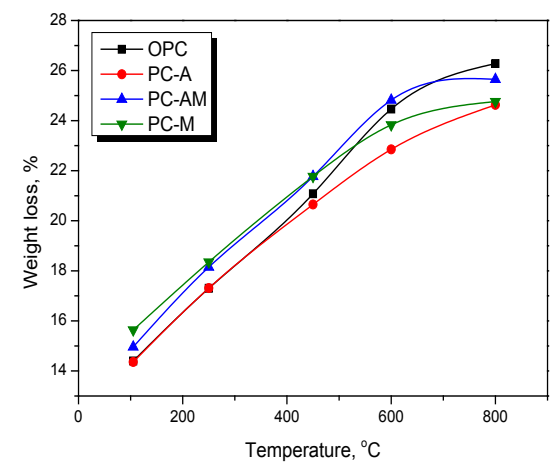

Fig. 13. Weight loss of hydrated OPC and composite cement pastes heat treated up to $800{ }^{\circ} \mathrm{C}$

Egypt.J.Chem. 60 , No.3 (2017) 
mations. The hydration products $\mathrm{C}-\mathrm{S}-\mathrm{H}$ and $\mathrm{CH}$, shrink due to dehydration. The un-hydrated clinker, however, expands due to thermal dilation. The micro-cracks in heated cement paste are caused by the strain mismatch of the shrinking hydration products and expanding clinker particles [40]. As a result of the shrinking microstructure, the porosity of the cement paste increases with temperature.

\section{Weight loss}

The weight loss of cement pastes heated treated up to $800{ }^{\circ} \mathrm{C}$ is represented in Fig. 13. The weight loss increases with temperature due to the removal of free water at $105{ }^{\circ} \mathrm{C}$, a partially decomposition of C-S-H, C-A-H and C-A-S-H. Moreover, the decomposition of gehlenite hydrate $\left(\mathrm{C}_{2} \mathrm{ASH}_{8}\right)$ takes place above $200{ }^{\circ} \mathrm{C}$ and dehydroxylation of $\mathrm{CH}$ at $450-550{ }^{\circ} \mathrm{C}$ [41]. Also, the decomposition of $\mathrm{CaCO}_{3}$ occurred at $600-800{ }^{\circ} \mathrm{C}$ [42]. The substitution of ASRBs with MK increases the weight loss due to the higher water of consistency of MK cement pastes. Mix PC-A and PC-AM give the lowest weight loss values at $800{ }^{\circ} \mathrm{C}$. This may be due to the pozzolanic activity of MK which consumes portlandite forming additional thermally stable minerals and decreases the micro-cracks as well as the high thermal stability of ASRBs.

\section{Bulk density}

The bulk density of cement pastes heated treated up to $800{ }^{\circ} \mathrm{C}$ is represented in Fig. 14. The bulk density of all cement pastes decreases from 105 to $250{ }^{\circ} \mathrm{C}$, due to the removal of free, adsorbed and some of combined water which leads to microcracks as well as increases the opening of the pore system of cement pastes. From 250 up to $800{ }^{\circ} \mathrm{C}$ the bulk density increases due to the additional hydration products as well as a result of the so-called internal autoclaving [42]; it is also due to the associated shrinkage from the removal of $\mathrm{H}_{2} \mathrm{O}$ and $\mathrm{CO}_{2}$ to give a dense structure [43]. Evidently, the bulk density decreases with MK content, due to the relatively higher water of consistency of MK cement pastes. MK has more pozzolanic property which acts as nucleating agent that increases the rate of hydration of cement to form more cementitious materials that fill some pores producing closed compact structure [33]. Mix PC-A gives higher bulk densty up to $800{ }^{\circ} \mathrm{C}$. This is due to the higher specific gravity of ASRBs than MK. The specific gravity of ASRBs and MK is 2.96 and $2.65 \mathrm{~g} / \mathrm{cm}^{3}$, respectively.

\section{Compressive strength}

Figure 15 shows the compressive strength of cement pastes with thermal treatment. It is clear that the compressive strength of heat treated of OPC pastes is lower than ASRBs/MK composite cement pastes. The compressive strength increases up to $250{ }^{\circ} \mathrm{C}$. This may be due to the additional hydraulic reaction of ASRBs and MK with portlandite to produce more hydraulic products such

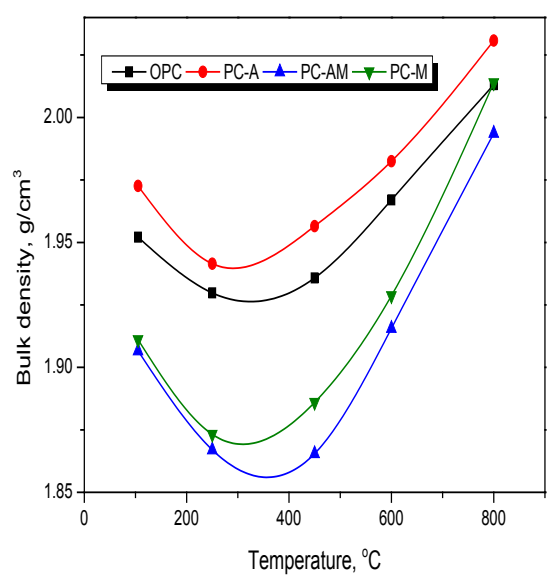

Fig. 14. Bulk density of OPC and composite cement pastes fired up to $800{ }^{\circ} \mathrm{C}$.

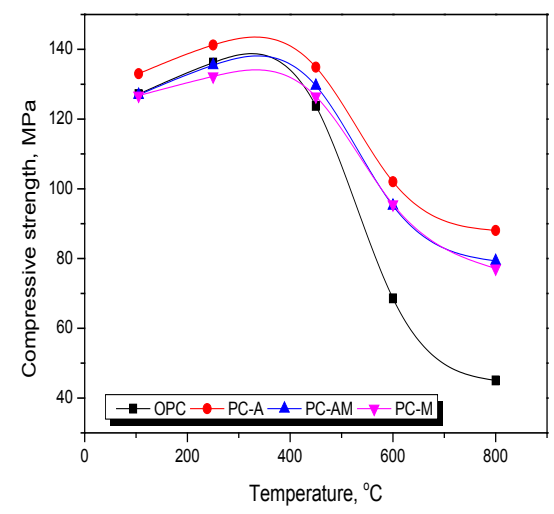

Fig. 15. Compressive strength of OPC and composite cement pastes fired up to $800{ }^{\circ} \mathrm{C}$. 
as C-S-H, C-A-H and C-A-S-H phases deposited in the pore system and also as a result of internal autoclaving effect [44]. The compressive strength of composite cement pastes start to decline at 450 ${ }^{\circ} \mathrm{C}$, which may be due to the dehydroxylation of the $\mathrm{Ca}(\mathrm{OH})_{2}$ producing $\mathrm{CaO}$ and $\mathrm{H}_{2} \mathrm{O}$. Over 450 up to $600{ }^{\circ} \mathrm{C}$, the relatively sharp reduction is mainly caused by dissociation of portlandite $(\mathrm{CH})$ giving $\mathrm{CaO}$ and water vapour. The compressive strength of all cement pastes decreases with lower rate up to $600{ }^{\circ} \mathrm{C}$. This is mainly due to, physical filler of pozzolana deposits in the porous system that leads to cross link which lowers the temperature gradient across this system. Therefore, the thermal stresses induced by heat flow may be considered a singular at the tip of cracks [45]. Up to $800{ }^{\circ} \mathrm{C}$ the compressive strength decreases for all cement pastes, this due to that the amorphous C-S-H starts to recrystallize into $\mathrm{B}-\mathrm{C}_{2} \mathrm{~S}$ or CS (wollastonite), when the temperature exceeds $700{ }^{\circ} \mathrm{C}$ the recrystallization of C-S-H causes shrinkage and changes the microstructure of compressive strength [46]. The PC-A is the optimum composite cement paste, which gives higher bulk density and compressive strength. It is found also that OPC pastes give the lower

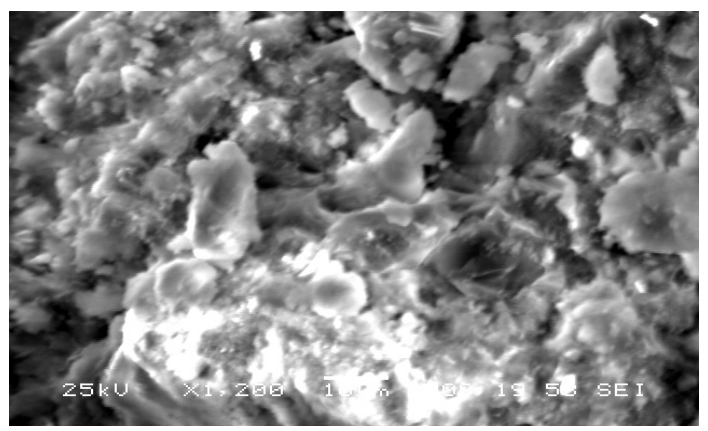

Fig. 16a . PC-A $\left(250^{\circ} \mathrm{C}\right)$.

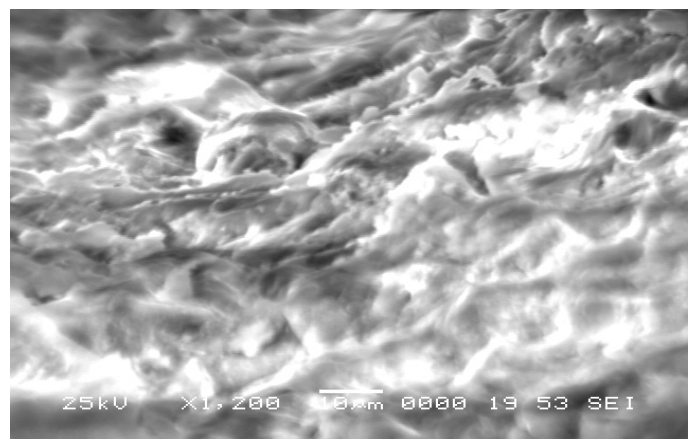

Fig. 16b PC-A $\left(450{ }^{\circ} \mathrm{C}\right)$. compressive strength up to $800{ }^{\circ} \mathrm{C}$. Therefore, the pozzolanic materials enhance the fire resistance of OPC pastes.

\section{SEM micrographs}

SEM micrographs of cement pastes thermally treated up to $800{ }^{\circ} \mathrm{C}$ are seen in Fig. 16a-c. The micrograph of PC-A displayed the presence of a nearly amorphous C-S-H and dense microstructure as shown in Fig. 16a. It was clear that, the microstructure of mix PC-A thermally treated at $250{ }^{\circ} \mathrm{C}$ was perfectly stable for thermal treatment and illustrates a dense structure of hydrated products as shown. Therefore, the replacement of OPC by $20 \mathrm{wt} \%$ of ASRBs resulted in an improvement of thermal stability of the hardened composite cement. At $450{ }^{\circ} \mathrm{C}$, the pores appear to increase in size and some micro-cracks also appear (Fig. 16b). Fig. 16c illustrates the SEM micrograph of treated at $800{ }^{\circ} \mathrm{C}$, it represents the formation of unhydrated phases such as $\beta_{-}-\mathrm{C}_{2} \mathrm{~S}, \mathrm{C}_{3} \mathrm{~S}$ and wollastonite due to the decomposition of C-S-H at higher temperature as well as the presence of some micro-cracks [19]. These micro-cracks tend to decrease the compressive strength.

The micrograph of PC-M pastes thermally treated up to $800^{\circ} \mathrm{C}$ is seen in Fig. $17 \mathrm{a}$-c. At $250^{\circ} \mathrm{C}$,

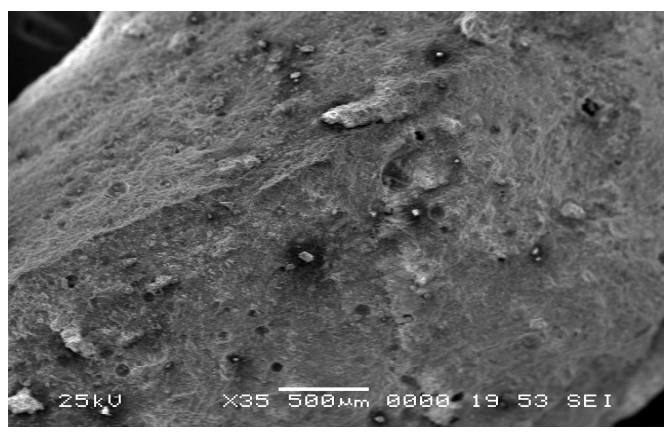

Fig. 16a . PC-A $\left(250{ }^{\circ} \mathrm{C}\right)$.

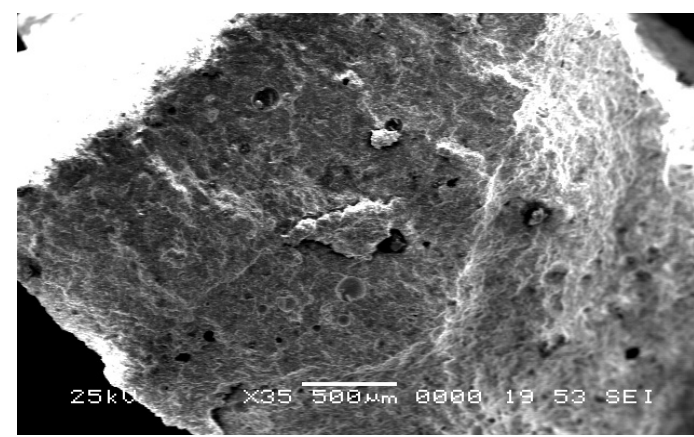

Fig. 16b PC-A $\left(450{ }^{\circ} \mathrm{C}\right)$.

Egypt.J.Chem. 60 , No.3 (2017) 


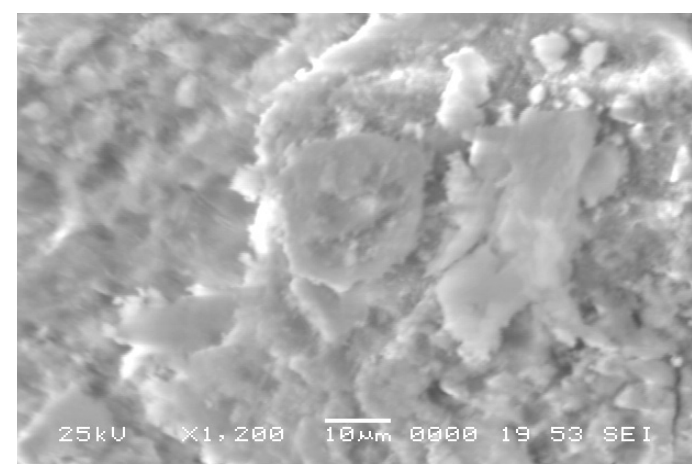

Fig. 16c .PC-A $\left(800^{\circ} \mathrm{C}\right)$.

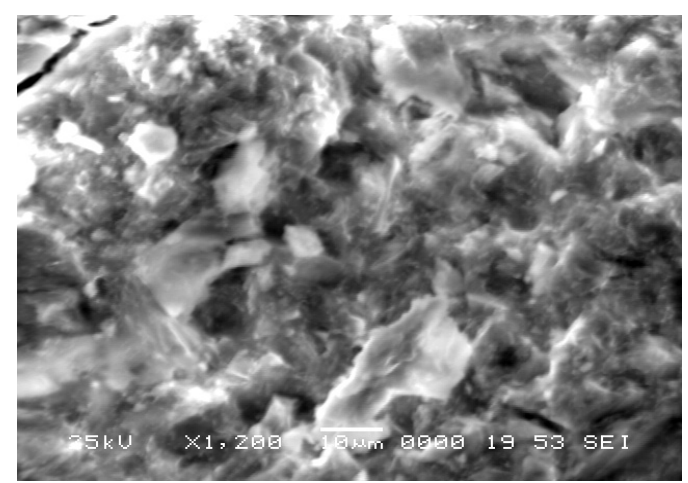

Fig. 17a . PC-M $\left(250^{\circ} \mathrm{C}\right)$.

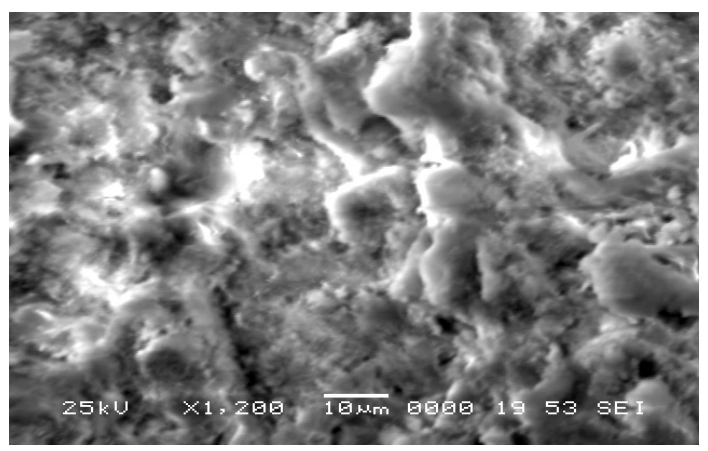

Fig. 17b .PC-M $\left(450{ }^{\circ} \mathrm{C}\right)$.

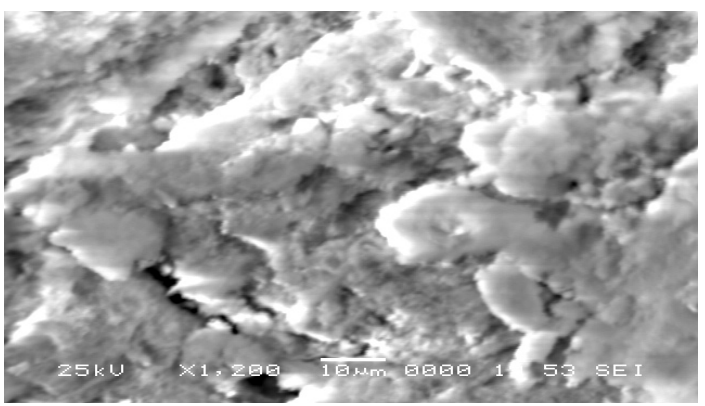

Fig. 17c . PC-M $\left(800{ }^{\circ} \mathrm{C}\right)$.

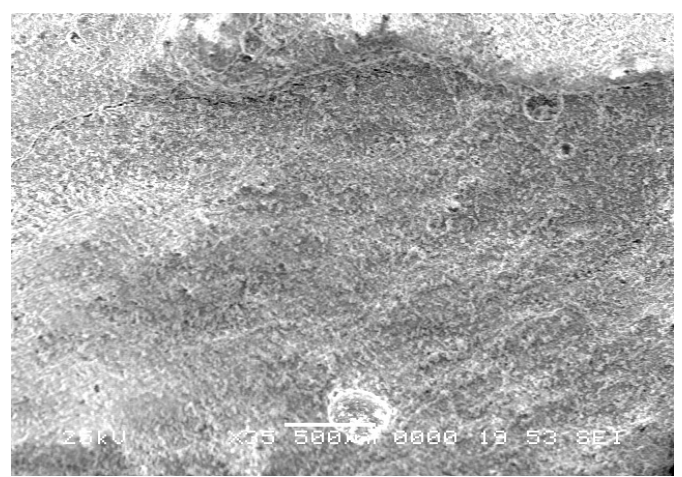

Fig. 16c . PC-A $\left(800{ }^{\circ} \mathrm{C}\right)$.

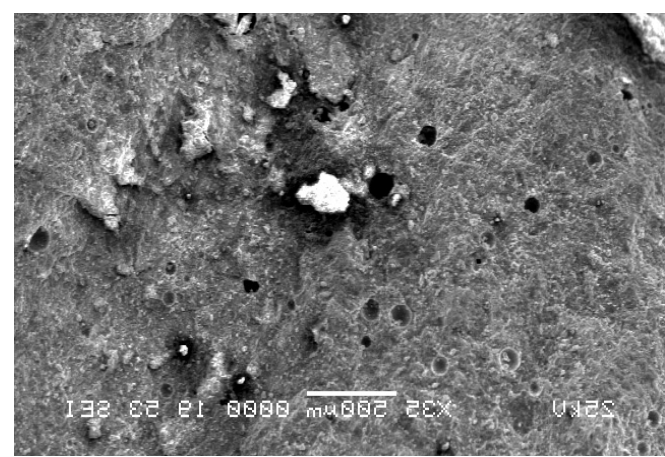

Fig. 17a . PC-M $\left(250^{\circ} \mathrm{C}\right)$.

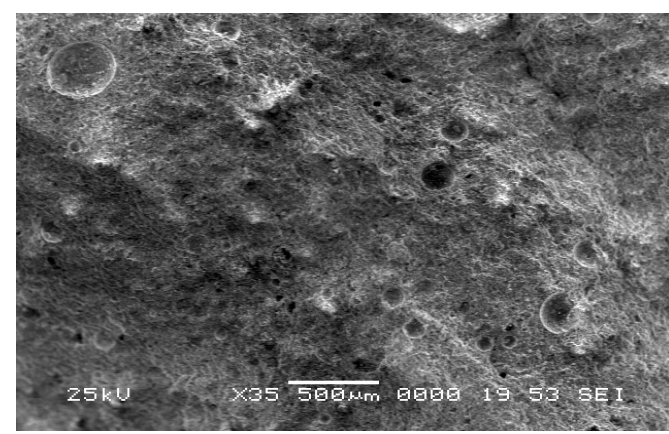

Fig. 17b. PC-M $\left(450{ }^{\circ} \mathrm{C}\right)$.

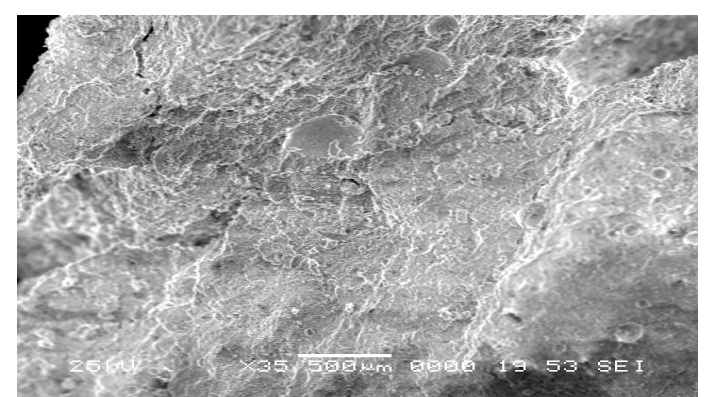

Fig. 17c . PC-M $\left(800{ }^{\circ} \mathrm{C}\right)$.

Egypt.J.Chem. 60 , No.3 (2017) 
it was clear that, the presence of pores nearly connected and adjusted to some large particles affected negatively on the strength (Fig. 17a). At $400{ }^{\circ} \mathrm{C}$, some micro-cracks start appearing and pores are slightly bigger than at $250{ }^{\circ} \mathrm{C}$ (Fig. 17b). Thermal treatment of mix PC-M at $800^{\circ} \mathrm{C}$ showed a decomposition of the hydration products with the formation of mico-craks in the structure as shown in Fig. $17 \mathrm{c}$.

\section{Conclusions}

When MK is substituted instead of ASRBs the water of consistency increases with MK, the initial and final setting times are retarded. The combined water increases due to the high water of consistency of cement pastes. The free lime content of cement pastes increases up to 7 days then decreases up to 90 days. The substitution of ASRBs to $20 \mathrm{wt} \%$ MK decreases the free lime up to 90 days due to its high pozzolanic activity than ASRBs. PC-M cement paste gives compressive strength nearly equal to the neat cement paste. The effect of fire on the mechanical properties of cement pastes was carried out by the determination of weight loss, bulk density and compressive strength of heat treated hardened cement pastes treated up to $800{ }^{\circ} \mathrm{C}$. Cement pastes containing $20 \mathrm{wt}, \%$ ASRBs (PC-A) is the optimum composite cement paste which gives high bulk density and compressive strength. PC-A mix has a good firs resistance paste.

\section{References}

1. Hewlett, P.C., Lea's Chemistry of Cement and Concrete, $5^{\text {th }}$ ed., Butterworth-Heinemann, (2016).

2. El-Didamony, H., Abd El-Rahman, E., Osman, R..M.. Fire resistance of fired clay bricks-fly ash composite cement pastes, Ceram Int 38, 201-209 (2012).

3. Mehta P.K., Advancements in concrete technology. Concr Int 96, 69-76 (1999).

4. Nadeem, A., Memon, S.A., Lo, T.Y., Mechanical performance, durability, qualitative and quantitative analysis of microstructure of fly ash and metakaolin mortar at elevated temperatures, Const Build Mater 38, 338-347 (2013).

5. Changling, H., Osbaeck, B., and Makovicky, E., Pozzolanic reaction of six principal clay minerals: activation reactivity assessments and techno-logical effects. Cem Concr Res 25(8), 1691-1702 (1995).

6. Zhang, M.H., and Malhotra,V.M., Characteristics of a thermally activated alumina silicate pozzolanic material and its use in concrete, Cement and Concrete Research, 25, 1713-1725 (1995).

7. Frías, M., Sánchez, de Rojas M.I., Cabrera, J. The effect that the pozzolanic reaction of metakaolin has on the heat evolution in metakaolin-cement mortars. Cem Concr Res 30(2), 209-216 (2000).

8. Qian, X.Q., and Li, Z.J., The relationships between stress and strain for high-performance concrete with metakaolin, Cement and Concrete Research, 31(11), 1607-1611 (2001).

9. Dinakar, P., Sahoo, P.K., Sriram, G. Effect of metakaolin content on the properties of high strength concrete. Inter J Concr Str Mater 7(3), 215-223 (2013).

10. El-Didamony, H., Amer, A.A., El-Sokkary, T.M., ElHoseny,S., Hydration and characteristics of metakaolin pozzolanic cement pastes, $\operatorname{HBR}(2016)$ (Article in Press).

11. El-Didamony, H., Amer, A.A., El-Hoseny, S., Recycling of low-grade aluminosilicate refractory brick waste product in blended cement, $J$ Therm Anal Calorim, (2016) DOI 10.1007/s10973-016-5431-9.

12. Bamonte, P., Gambarova, P.G., Meda, P. Today's concretes exposed to fire-test results and sectional analysis Struct Concr 9(1), 19-29 (2008).

13. Mehta, P.K., Monteiro, P.J.M. Concrete: Structure, Properties And Materials, Prentice-Hall, Englewood Cliffs, NJ, USA (1993)

14. Arioz,O. Effects of elevated temperatures on properties of concrete. Fire Saf J 42, 516-22 (2007).

15. Gai-Fei, P., Zhi-Shan, H., Change in microstructure of hardened cement paste subjected to elevated temperatures, Constr Build Mater, 22(4), 593-599 (2008).

16. Morsy, M.M., Shebl ,S.S., and Rashad, A.M., Effect of fire on microstructure and mechanical properties of blended cement pastes containing metakaolin and silica fume, Asian Journal of Civil Engineering (Building and Housing), 9(2), 93-105 (2008).

17. Morsy, M.S,. Rashad, A.M., El-Nouhy, H.A. Effect of elevated temperature on physico-mechanical properties of metakaolin blended cement mortar. Struct Eng Mech 31, 1-10(2009)

18. Koksal, F., Gencel, O., Brostow, W., Hagg Lobland ,H.E., Effect of high temperature on mechanical and physical properties of lightweight cement based refractory including expanded vermiculite, Materials Research Innovations, 16(1),7-13 (2012).

19. Heikal, M., El-Didamony, H., Sokkary, T.M., Ahmed, I.A., Behavior of composite cement pastes containing microsilica and fly ash at elevated temperature, Construction and Building Materials 38,1180-1190 (2013).

20. Topçu, I., Demir, A., Durability of rubberized mortar and concrete, J. Mat Civ Eng.,19(2),173-178 (2007).

Egypt.J.Chem. 60 , No.3 (2017) 
21. Poon, C.S., Azhar, S., Anson, M., Wong, Y.L., Comparison of the strength and durability performance of normal and high-strength pozzolanic concretes at elevated temperatures. Cem Concr Res 31(9), 1291-300 (2001).

22. Bingol, A.F., Gul. R., Compressive strength of lightweight aggregate concrete exposed to high temperatures, Indian J Eng Mater Sci, 11 68-72 (2004).

23. Poon, C.S., Shui, Z.H., Lam, ., Compressive behavior of fiber reinforced high-performance concrete subjected to elevated temperature, $\mathrm{Cem}$ Concr Res, 34,2215-2222 (2004).

24. ASTM Designation: C 204-07, Standard Test Methods for Fineness of Hydraulic Cement by AirPermeability Apparatus, ASTM Annual Book of ASTM Standards (2007).

25. ASTM Designation: C191 - 08, Standard Test Methods for Time of Setting of Hydraulic Cement by Vicat Needle, ASTM Annual Book of ASTM Standards, (2008).

26. El-Didamony H, Sharara AM, Helmy IM, AbdelAleem S. Hydration characteristics of $\beta-C 2 S$ in the presence of some accelerators. Cem Concr Res. 26(8), 1179-87 (1996).

27. ASTM Designation: C 114-07, ASTM C 114 Chemical Analysis of Hydraulic Cement, ASTM Annual Book of ASTM Standards (2007).

28. ASTM Designation; C 150, Standard test methods for compressive strength of hydraulic cements. ;710-73 (2007).

29. Plummer, L.N., Mackenzie, F.T., Predicting mineral solubility from rate data: Application to the dissolution of magnesian calcites. American Journal of Science, 27 (4), 61-83 (1974).

30. Ramachandran, V.S., Beaudoin, J.J., Handbook Of Analytical Techniques In Concrete Science And Technology. Principles, Techniques And Applications. New York, USA: Noyes Publications, 1999.

31. Kannan, V., Ganesan, K,. Evaluation of mechanical and permeability related properties of self compacting concrete containing metakaolin, Scientific Research and Essays,7(47),4081 -4091 (2012).

32. Naik, T.R., Singh, S.S., and Hossain, M.M., Permeability of high-strength concrete containing low cement factor, Journal of Energy Engineering, 122(1), 21-39(1996).

33. Vlasov, V.K., Mechanisms for increase of concrete strength while introducing micro-filler, Concrete and Reinforced Concrete, 10, 9-11 (1988).

Egypt.J.Chem. 60 , No.3 (2017)
34. Mehta, P.K., Pozzolanic and cementitious byproducts in concrete -another look, Proceedings of the Third International Conference on the Use of Fly Ash, Silica Fume, Slag and Other Natural Pozzolans, ACI SP-144, 1 1-43 (1989).

35. Esteves, L.P. On the hydration of water-entrained cement-silica system combined SEM, XRD and thermal analysis in cement pastes. Thermochim Acta:;518, 27-35 (2011).

36. Antoni, M., Rossen, J., Martirena, F., Scrivener,K. Cement substitution by a combination of metakaolin and limestone. Cem Concr Res. 42(12),1579-89 (2012).

37. Vedalakshmi, R. Quantification of hydrated cement products of blended cements in low and medium strength using TG and DTA technique. Thermochim Acta. 407,49-60 (2003).

38. Echart, A., Ludwig, H.M., Stark, J. Hydration of the four main Portland cement clinker phases. Zem Kalk Gip. 28(8), 443-52 (1995).

39. Caldarone, M.A., Gruber. K.A., and Burg, R.G., High reactivity metakaolin (HRM): a new generation mineral admixture for high performance concrete, Concrete International, 16(11), 37-40 (1994).

40. Piasta, J. Heat deformations of cement pastes phases and the microstructures of cement paste. Mater Struct, 17(102), 415-20 (1984).

41. Cook,R.A., Hover. K.C. Mercury porosimetry of hardened cement pastes. Cem Concr Res 29, 933 (1999).

42. Morsy, M.S., Galal. A.F., Abo-El-Enein, S.A. Effect of temperature on phase composition and microstructure of artificial pozzolana cement pastes containing burnt kaolinite clay. Cem Concr Res 28(8), 1157-63 (1998).

43. Heikal, M., Effect of temperature on the physicomechanical and mineralogical properties of Homra pozzolanic cement pastes, Cem Concr Res,30(11) ,1835-1839 (2000).

44. Nassif, A,Y., Burley, E., and Rigden, S., A new quantitative method of assessing fire damage to concrete structures, Magazine of Concrete Research, 47(172), 271-278 (1995).

45. Morsy,M.S, Physico-mechanical studies on thermally treated concrete. Ph.D. Thesis, Ain Shams University, Egypt, (1996).

46. Zhang, Q, Microstructure and deterioration mechanisms of Portland cement paste at elevated temperature, Ph.D Thesis, Technische Universiteit Delft, (2013).

Received 12/7/2016 Accepted $25 / 7 / 2016$ 


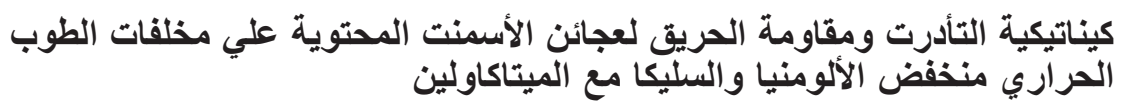

أحمد عبدالمنعم احمد عامر و سميرمحمد الحسيني

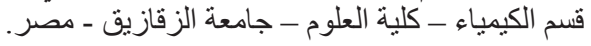

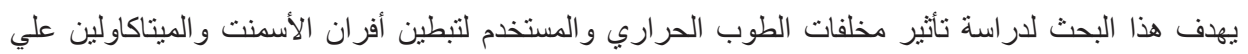

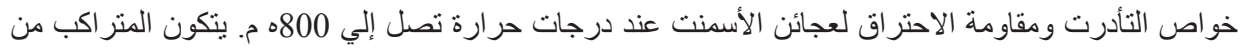

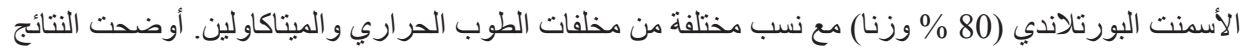

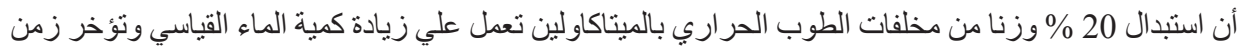

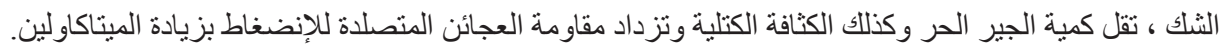

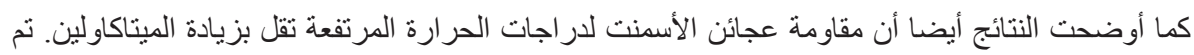

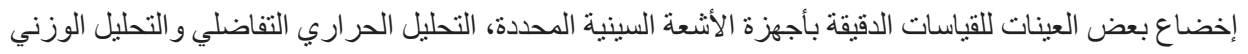

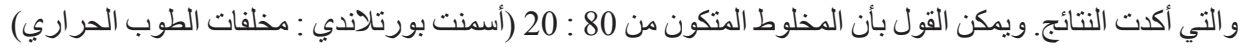

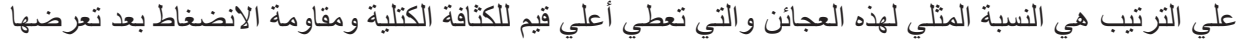
ل الدات الحريق المرتفعة. 